\title{
Pegylated interferon induced interstitial pneumonitis in a patient with hepatitis $\mathbf{C}$ infection
}

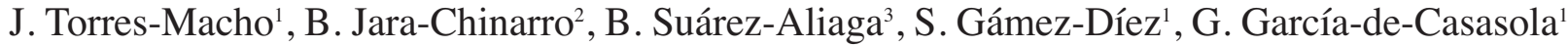 \\ and B. de-Cuenca-Morón ${ }^{4}$
}

Servicios de ${ }^{1}$ Medicina Interna, ${ }^{2}$ Neumología, ${ }^{3}$ Radiología $y{ }^{4}$ Medicina de Aparato Digestivo. Hospital Infanta Cristina. Parla. Madrid, Spain

\begin{abstract}
Pegylated interferon and ribavirin is the treatment of choice in patients with chronic hepatitis $\mathrm{C}$ infection. The most common side effects of interferon therapy are flu-like symptoms and psychiatric disorders. Pneumonitis is a less frequent complication associated with non-negligible mortality. We herein report a case of interferon associated pneumonitis in a patient with non-severe clinical symptoms and a normal chest radiography. Physicians should be aware of this entity during the differential diagnosis of respiratory symptoms in patients receiving treatment with interferon due to its high morbimortality and good resolution and outcome after drug withdrawal.
\end{abstract}

Key words: Interferon. Neumonitis. Hepatitis C.

\section{RESUMEN}

El interferón pegilado asociado a ribavirina es el tratamiento de elección en los pacientes con infección por hepatitis $C$ crónica. Los efectos secundarios más comunes son los síntomas gripales y las alteraciones psiquiátricas. La neumonitis es una complicación poco frecuente, pero se asocia con una mortalidad no despreciable. Presentamos el caso clínico de un paciente con neumonitis intersticial asociada a interferón que presentaba signos y síntomas clínicos sutiles y una radiografía de tórax sin alteraciones. Se debe de tener presente esta entidad en el diagnóstico diferencial de los síntomas respiratorios en pacientes que reciben tratamiento con interferón debido a su elevada morbi-mortalidad y a su evolución favorable tras la retirada del fármaco

Palabras clave: Interferón. Neumonitis. Hepatitis C.

Recibido: 06-04-10.

Aceptado: $13-00-10$.

Correspondencia: Juan Torres Macho. C/ Numancia 6, 4º-8. 28039 Madrid.e-mail: jtorresmacho@gmail.com
Torres-Macho J, Jara-Chinarro B, Suárez-Aliaga B, Gámez-Díez $S$, García-de-Casasola G, de-Cuenca-Morón B. Pegylated interferon induced interstitial pneumonitis in a patient with hepatitis $C$ infection. Rev Esp Enferm Dig 2010; 102: 606-608.

\section{INTRODUCTION}

Chronic hepatitis $\mathrm{C}$ virus (HCV) infection may result in liver cirrhosis and hepatocellullar carcinoma (1). A combination of pegylated interferon alpha and ribavirin is the treatment of choice (2). The most frequent side effects of interferon therapy are flu-like symptoms, psychiatric disorders and hematological alterations such anemia (3). Interstitial lung disease is a known rare adverse event that often leads to discontinuation of therapy because of its significant morbidity and mortality (4).

\section{CASE REPORT}

A 57-year-old man, with a history of well-controlled intrinsic asthma treated with long acting $\beta-2$ adrenergic agonists and inhaled steroids. The patient was diagnosed of chronic hepatitis C (genotype 1b) in 1991. The infection was probably acquired by blood transfusion during childhood. In 2004, treatment with pegylated interferon and ribavirin was initiated due to a high viral load and a moderate necro-inflammation found on the liver biopsy. However, treatment was withdrawn due to side effects (anemia and neutropenia). Although there was a persistence of RNA in serum, there was a biochemical response with normalization of liver function tests. In February 2009, the presence of mildly elevated transaminase serum levels and a RNA viral load of 8.218.400 UI/ml was detected. A transient elastography $\left(\right.$ Fibroscan $\left.^{\circledR}\right)$ was performed showing a liver stiffness of $10.4 \mathrm{kPA}(\mathrm{F} 3)$, thus treatment with pegylated 
interferon $2 \mathrm{~b}(100 \mathrm{mcgr} /$ weekly) and ribavirin (1000 mgr twice a day) was initiated.

Twelve weeks after treatment began the patient presented to the emergency department with a history of progressive dyspnea at minimal efforts. The vital signs on admission were as follows: blood pressure 120/70 $\mathrm{mmHg}$, a respiratory rate of 16 breaths per minute, a heart rate of 80 beats per minute and an axillary temperature of $36.7{ }^{\circ} \mathrm{C}$. Physical examination was unremarkable. Basal oxygen saturation was $96 \%$. The hemogram and biochemistry showed no abnormalities except for mild anemia (hemoglobin de $9.6 \mathrm{~g} / \mathrm{dL}$, hematocrit $31.3 \%$ and a mean corpuscular volume of $112 \mathrm{fL}$ ). Arterial blood gases showed: $\mathrm{Ph} 7.55, \mathrm{PO}_{2} 103$ $\mathrm{mmHg}$ and $\mathrm{PCO}_{2} 24 \mathrm{mmHg}$. A Chest X-ray showed no abnormalities (Fig 1).

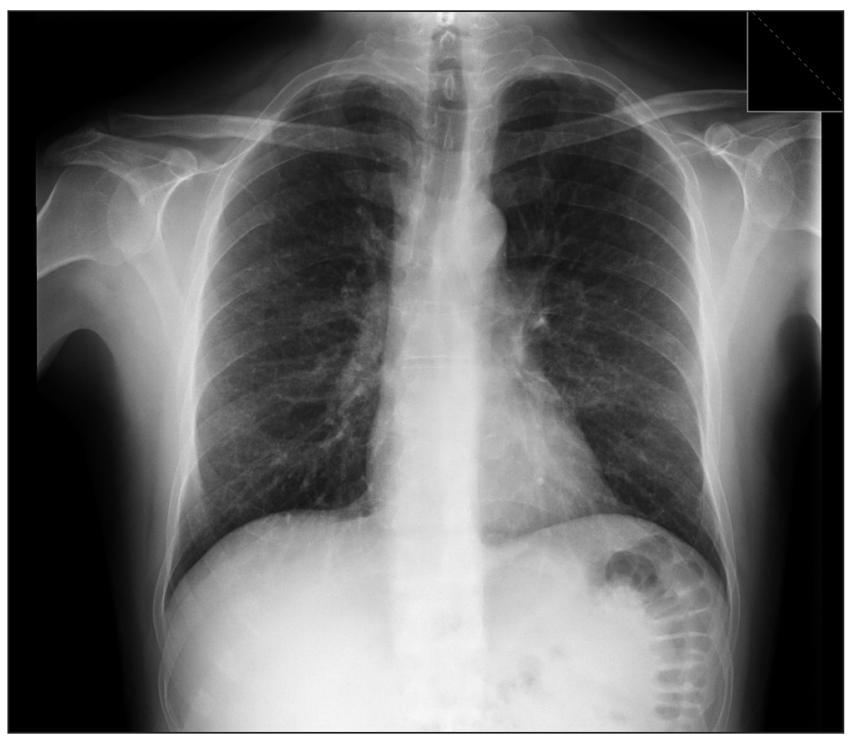

Fig. 1. Chest $X$ ray showing no abnormalities.

Cutaneous oxygen saturation was assessed after a moderate effort (walking on a level surface) showing a significant desaturation (down to 90\%). Pegylated interferon and ribavirin were withdrawn and a chest high resolution CT was performed the next day demonstrating bilateral, multifocal, patchy ground-glass opacities of peripheral location (Fig 2). Pulmonary function tests showed no restriction or obstruction with a diminished diffusion capacity. Broncoalveolar lavage was performed to rule out an infectious origin. The results of strains were negative for bacteria, fungi, acid-fast bacteria, virus and malignant cells. After interferon and ribavirin was withdrawn the patient presented a slow amelioration of dyspnea and after eight weeks, symptoms disappeared completely with a normalization of pulmonary function tests.

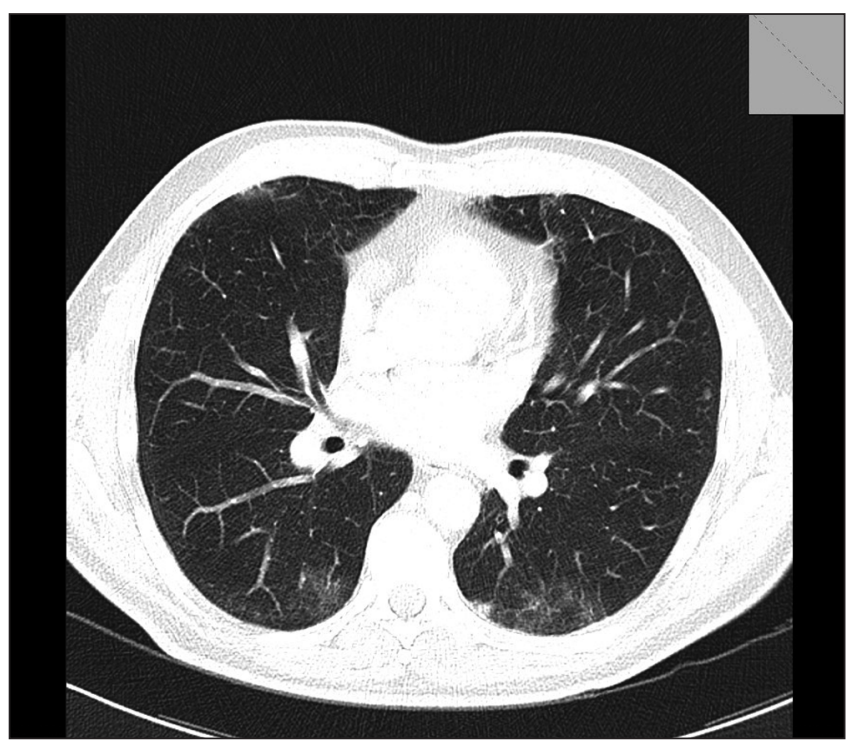

Fig. 2. Chest CT showing bilateral, parchy ground-glass opacities of peripheral location.

\section{DISCUSSION}

Hepatitis C infections become chronic in up to $85 \%$ of patients. Pegylated interferon and ribavirin are the mainstay of treatment (5). Pegylation is the attachment of an inactive, polyethylene glycol moiety to the conventional interferon molecule. The resulting compound has a sustained absorption, high blood levels and a prolonged half-life (6, 7). Sustained virological response (SVR) is defined as the presence of HCV RNA negative 24 weeks after cessation of treatment which usually leads to resolution of hepatic inflammation and regression of fibrosis. SVR can be achieved in up to 36 to $75 \%$ of patients, depending on many factors like age, genotype, viral load, grade of fibrosis, etc. $(2,8)$. Pulmonary side effects like asthma exacerbation, pleural effusion, sarcoid-like reaction, bronchiolitis obliterans organizing pneumonia and interstitial pneumonitis have been described $(6,9)$.

The mechanism of this side effect remains unclear but it is supposed to be idiosyncratic and it is probably related to interferon inmunomodulatory activity that includes induction of enzymes, suppression of cell proliferation, enhancement of macrophage phagocytic activity, inhibition of suppressor T cells and liberation of proinflammatory cytokines (10-12). It remains unclear if pharmacokinetic properties of peginterferon compared to conventional interferon are linked to an increased toxicity $(4,6)$. Although ribavirin can cause dry cough and dyspnea, there are no documented cases of pathologic pulmonary toxicity due to ribavirin therapy alone.

The clinical presentation of interstitial pneumonitis is usually insidious at the onset. The most common symptoms associated with pneumonitis are cough, fever, dysp- 
nea and fine dry crackles in pulmonary auscultation. It is not a frequent side effect The incidence of pneumonitis is not a frequent side effect and is experienced in less than $1 \%(13,14)$. To date, about 60 cases have been reported in the literature (4). Differential diagnosis include infections like viral respiratory processes, atypical pneumonia or mycobacterial infection and congestive heart failure. Chest radiographs may be normal, but usually show bilateral interstitial infiltrates. High resolution CT scan may show bilateral patchy consolidation as well as ground glass attenuation (15).

There is no consensus regarding treatment although the cornerstone of management is to stop using the offending drug. Different options have been described ranging from drug withdrawal to steroid addition or treatment with azatioprin in steroid resistant patients $(6,16)$. A high mortality rate $(7 \%)$ have been found and most patients did not have relevant pulmonary or other previous severe disease (4).

In our case study, clinical exploration and chest X-ray showed no alterations; however, symptoms and physical signs suggested a lung diffusion alteration (oxygen desaturation while walking) and led us to the diagnosis. Given the clinical stability, we decided not to treat with steroids.

Clinicians should be aware of pneumonitis development in patients treated with pegylated interferon who develop pulmonary symptoms like cough or dyspnea, even with an unremarkable exploration and a normal chest X-ray. It is a severe complication and it needs to be recognized in order to prevent lung damage and/or progression to pulmonary fibrosis and death.

\section{REFERENCES}

1. Lauer GM, Walker BD. Hepatitis C virus infection. N Engl J Med. $2001 ; 345: 41-52$.
2. Ghany MG, Strader DB, Thomas DL, Seeff LB. Diagnosis, management, and treatment of hepatitis C: An update. Hepatology 2009; 49: 1335-74.

3. Fried MW. Side effects of therapy of hepatitis $\mathrm{C}$ and their management. Hepatology 2002; 36: S237-44.

4. Slavenburg S, Heijdra YF, Drenth JP. Pneumonitis as a consequence of (peg)interferon-ribavirin combination therapy for hepatitis C: A review of the literature. Dig Dis Sci; 2009.

5. Hoofnagle JH, Seeff LB. Peginterferon and ribavirin for chronic hepatitis c. N Engl J Med 2006; 355: 2444-51.

6. Midturi J, Sierra-Hoffman M, Hurley D, Winn R, Beissner R, Carpenter J. Spectrum of pulmonary toxicity associated with the use of interferon therapy for hepatitis C: Case report and review of the literature. Clin Infect Dis. 2004; 39: 1724-9.

7. Abi-Nassif S, Mark EJ, Fogel RB, Hallisey RK, Jr. Pegylated interferon and ribavirin-induced interstitial pneumonitis with ards. Chest. 2003; 124: 406-10

8. Aguilar Reina J. Viral dynamics and prediction of response to treatment with pegylated interferon and ribavirin in patients with chronic hepatitis C. Rev Esp Enferm Dig 2009; 101: 665-70.

9. Kumar KS, Russo MW, Borczuk AC, Brown M, Esposito SP, Lobritto SJ, et al. Significant pulmonary toxicity associated with interferon and ribavirin therapy for hepatitis C. Am J Gastroenterol 2002; 97: 2432-40.

10. Tilg H. New insights into the mechanisms of interferon alfa: An immunoregulatory and anti-inflammatory cytokine. Gastroenterology 1997; 112: 1017-21.

11. Borden EC, Parkinson D. A perspective on the clinical effectiveness and tolerance of interferon-alpha. Semin Oncol 1998; 25: 3-8.

12. Dalgard O, Bjoro K, Hellum K, Myrvang B, Bjoro T, Haug E, Bell $\mathrm{H}$. Thyroid dysfunction during treatment of chronic hepatitis $\mathrm{c}$ with interferon alpha: No association with either interferon dosage or efficacy of therapy. J Intern Med 2002; 251: 400-6.

13. Okanoue T, Sakamoto S, Itoh Y, Minami M, Yasui K, Sakamoto M, et al. Side effects of high-dose interferon therapy for chronic hepatitis C. J Hepatol 1996; 25: 283-91.

14. Manns MP, McHutchison JG, Gordon SC, Rustgi VK, Shiffman M, Reindollar R, et al. Peginterferon alfa-2b plus ribavirin compared with interferon alfa-2b plus ribavirin for initial treatment of chronic hepatitis C: A randomised trial. Lancet 2001; 358: 958-65.

15. Park JS, Lee KS, Kim JS, Park CS, Suh YL, Choi DL, et al. Nonspecific interstitial pneumonia with fibrosis: Radiographic and ct findings in seven patients. Radiology 1995; 195: 645-8.

16. Chin K, Tabata C, Sataka N, Nagai S, Moriyasu F, Kuno K. Pneumonitis associated with natural and recombinant interferon alfa therapy for chronic hepatitis C. Chest 1994; 105: 939-41. 